\title{
O PRECEDENTE JUDICIAL COMO FONTE PRIMÁRIA DO DIREITO ELEITORAL
}

\author{
The precedent as a primary source of election law
}

Rodrigo Cyrineu

Resumo: Ao longo dos últimos anos, o Poder Judiciário vem exercendo, cada dia mais, o seu papel de "guardador das promessas" constitucionais, para parafrasear Antoine Garapon. Com isso, sua atuação se acentuou significativamente. Em paralelo, os legisladores estão elaborando leis cada vez mais enxutas e com textos mais abertos, propiciando um maior espaço interpretativo às Cortes. Atento a isso, o artigo se propõe a revisitar o papel dos precedentes no sistema brasileiro.

Palavras-chave: Precedentes. Fontes primárias do direito. Positivismo. Direito Eleitoral.

\begin{abstract}
Over the past few years, the brazilian judiciary has increasingly exercised its role as the "promise-keeper" of the constitution to paraphrase Antoine Garapon. With this, its performance was significantly enhanced. At the same time, legislators are drafting increasingly leaner laws with more open texts, providing greater interpretative space for the courts. Given this, the article proposes to revisit the role of precedents in the Brazilian system.
\end{abstract}

Keywords: Precedents. Primary source. Positivism. Election law. 


\section{Introdução}

A busca por cada vez mais segurança jurídica não é nova e não é exclusiva do ordenamento brasileiro. Todos os sistemas jurídicos ${ }^{1}$, em maior ou menor medida, buscaram, e ainda buscam, conferir maiores previsibilidade e estabilidade ao direito.

A novidade, pelo menos em terrae brasilis, é a exigência de segurança jurídica ${ }^{2}$ nas abruptas alterações jurisprudenciais, notadamente no cam- po eleitoral, o que pressupõe um novo olhar sobre os precedentes enquanto fontes do direito ${ }^{3}$.

Para melhor compreender essa nova postura, é preciso entender, em primeiro lugar, o método da(o) subsunção $4 /$ silogismo próprios do positivismo jurídico, e como esse modelo de pensamento jurídico ignorava ${ }^{5}$,

\footnotetext{
${ }^{1}$ É o que relata o ex-Justice Benjamin Cardozo, membro da Suprema Corte norte-americana: "Em meus primeiros anos como juiz, era tamanha minha perturbação de espírito que eu não conseguia perceber que não havia rastros ou vestígios no oceano em que me lançara. Eu buscava a certeza". (CARDOZO, Benjamin Nathan. A natureza do processo judicial. Tradução de Silvana Vieira. São Paulo: Martins Fontes, 2004. p. 123).

${ }^{2}$ MITIDIERO, Daniel. Cortes Superiores e Cortes Supremas: do controle à interpretação, da jurisprudência ao precedente. 3. ed. São Paulo: Revista dos Tribunais, 2017. p. 17: "a segurança jurídica impõe imediatamente a imprescindibilidade de o direito ser cognoscível, estável, confiável e efetivo, mediante a formação e o respeito aos precedentes como meio geral para obtenção da tutela dos direitos. O foco direto aí é a ordem jurídica e a sociedade civil como um todo".
}

${ }^{3}$ STRECK, Lenio Luiz. Precedentes judiciais e hermenêutica: o sentido da vinculaçãono CPC/2015. Salvador: Juspodivm, 2018. O livro, como reconhecido pelo próprio autor (p. 9), "trata de uma questão urgente para o direito brasileiro: a suposta criação de um 'sistema brasileiro de precedentes', ou 'sistema de criação de teses judiciais', chegando a se falar até de stare decisis como coro-amento de um Common Law à brasileira".

${ }^{4}$ De acordo com os levantamentos de MACÊDO, Lucas Buril de. Precedentes judiciais e o direito processual civil. Salvador: Juspodivm, 2015. p. 43, ao estudar a história do civil law, berço do positivismo legalista, neste sistema partia-se do pressuposto de que "os juristas devem raciocinar de forma dedutiva, e é defendido por muitos que a lógica subsuntiva é a forma de raciocínio adequada e suficiente para a aplicação da norma: caberia tão só elevar os fatos às normas, trabalhar os seus conceitos e classificações, chegando à conclusão dada pelo sistema”.

${ }^{5}$ MacCORMICK, Neil. Argumentação jurídica e Teoria do Direito. Tradução de Waldéa Barcellos. 2. ed. São Paulo: Martins Fontes, 2009. p. XV (preâmbulo de 1994): “(...) a argumentação a partir de normas somente pode nos levar até certo ponto; e é inerente à própria natureza do direito que as normas com frequência fiquem aquém de sua própria virtude essencial, revelando-se vagas para um determinado contexto prático". 
dadas as suas premissas ${ }^{6}$ (dentre elas, a que se destaca é o "livre convencimento"7), o papel do Judiciário (em especial, o das Cortes Supremas) na aplicação do direito e sua inexorável influência na sua criação e no seu redesenho.

Além disso, e ainda no contexto da antiga dogmática, é forçoso analisar de que forma a incompletude do ordenamento jurídico era tratada e de como esse tratamento exigiu uma nova postura interpretativa, sobremodo com a utilização de conceitos jurídicos indeterminados ${ }^{8}$.

Posteriormente, importa delinear os traços do novo modelo de pensamento jurídico decorrente do pós-positivismo, embalado pelo giro linguístico-hermenêutico da filosofia, para assim entender a reposição das

\footnotetext{
${ }^{6}$ MARINONI, Luiz Guilherme. O precedente na dimensão da segurança jurídica. In: MARINONI, Luiz Guilherme (coord.). A força dos precedentes: estudos dos cursos de Mestrado e Doutorado em Direito Processual Civil da UFPR. Salvador: Juspodivm, 2010. p. 214: "Sublinhe-se que o common law, que certamente confere maior segurança jurídica do que o civil law, não relaciona a previsibilidade com o conhecimento das leis, mas sim com a previsibilidade das decisões do Poder Judiciário. $O$ advogado de common law tem possibilidade de aconselhar o jurisdicionado porquepode se valer dos precedentes, a contrário daquele que atua no civil law, que é obrigado a advertir o seu cliente que determinada lei pode - conforme o juiz sorteado para analisar o caso - ser interpretada em seufavor ou não. A lógica desta tradição não apenas é inversa, e assim faz surgir a nítida impressão de que o direito do civil law não é tão certo quanto o direito do common law, como milita e se volta contra o próprio sistema, na medida em que estimula a propositura de ações, o aumento da litigiosidade, o acúmulode trabalho e o aprofundamento da lentidão do Poder Judiciário".

${ }^{7}$ Como já advertido, grande parte dos pensadores ainda se calcam na ideia de autonomia irrestrita do magistrado no caso concreto. Por todos, CANOTILHO, José Joaquim Gomes. Direito Constitucional e Teoria da Constituição. 7. ed. Coimbra: Almedina, 2003. p. 265. Daí a crítica de Lenio Luiz Streck [In O que é isto: decido conforme minha consciência? 2. ed. Porto Alegre: Livraria do Advogado, 2010. p. 19]: “O que é importante ressaltar aqui é que o problema da verdade - e, portanto, da manifestação da verdade no próprio ato judicante - não pode se reduzir a um exercício de vontade do intérprete (julgar conforme sua consciência), como se a realidade fosse reduzida à sua representação subjetiva".

8 "Conceitos indeterminados acabam por implicar que o futuro também possa ser regulado pela norma. Em muitos casos, o conteúdo do conceito está para ser construído e a norma contém balizar para absorver parte da realidade que ainda não existe no presente". (ALVIM, Teresa Arruda; DANTAS, Bruno. Recurso Especial, Recurso Extraordinário e a nova função dos Tribunais Superiores. 5. ed. rev. e atual. São Paulo: Revista dos Tribunais, 2018. p. 209)
} 
fontes primárias do direito ${ }^{9}$, com especial enfoque aos precedentes ${ }^{10}$ (jurisprudência), dado o papel de destaque do aplicador do direito, agora devidamente reconhecido ${ }^{11}$.

Com isso, é forçoso averiguar em que medida o sistema brasileiro, notoriamente de origem continental (civil law), aproxima-se do modelo anglo-americano de direito (common law), com enfoque especial no stare decisis ${ }^{12} \mathrm{e}$ no papel das Cortes de Ápice.

\section{O positivismo jurídico}

Atualmente, é possível dizer, sem parecer exagero, que é "completamente absurdo supor que a decisão judicial que se vale da lei pode variar livremente de sentido sem gerar insegurança"13-14. Mas nem sempre foi assim.

As teorias positivistas, em maior ou menor escala, tiveram como pressuposto essencial neutralizar o Judiciário de questões políticas ${ }^{15}$. A

\footnotetext{
${ }^{9}$ DINIZ, Maria Helena. op. cit., p. 285: "As fontes formais são os modos de manifestação do direito mediante os quais o jurista conhece e descreve o fenômeno jurídico. Logo, quem quiser conhecer o direito deverá buscar a informação desejada nas suas fontes formais, ou seja, na lei, nos arquivos de jurisprudência, nos tratados doutrinários. O órgão aplicador, por sua vez, também recorre a elas, invocando-as como justificação da sua norma individual'.

${ }^{10}$ MARINONI, Luiz Guilherme. op. cit., p. 214: "Ora, se a previsibilidade não depende da norma em que a ação se funda, mas da sua interpretação judicial, é evidente que a segurança jurídica está ligada à decisão judicial e não à norma jurídica em abstrato".

${ }^{11}$ MARINONI, Luiz Guilherme. A Ética dos Precedentes: justificativa do Novo CPC. 2. ed. rev. e atual. São Paulo: Revista dos Tribunais, 2016. p. 93: "O juiz colabora com o legislador para a frutificação do direito; não é mais seu servo, como coerentemente teria que admitir o adepto da ideia de que o juiz é submetido apenas à lei".

${ }^{12}$ Sobre a origem do termo stare decisis, confira-se: "This obligation of a court to follow its own previous decisions is typically known as stare decisis - Latin for 'stand by the thing decided' - and it is a distinct form of constraint by precedent" (SCHAUER, Frederick. Thinking like a lawyer: a new introduction to legal reasoning. Cambridge: Harvard University Press, 2012. p. 37).

${ }^{13}$ MARINONI, Luiz Guilherme. O precedente na dimensão da segurança jurídica. In: MARINONI, Luiz Guilherme (coord.). A força dos precedentes: estudos dos cursos de Mestrado e Doutorado em Direito Processual Civil da UFPR. Salvador: Juspodivm, 2010. p. 217.

${ }^{14}$ STRECK, Lenio Luiz. O que é isto: decido conforme minha consciência? 2. ed. Porto Alegre: Livraria do Advogado, 2010. p. 65: "É também na intepretação como 'ato de vontade' que faz. morada a discricionariedade positivista".

${ }^{15}$ FERRAZ JUNIOR, Tércio Sampaio. O direito, entre o futuro e o passado. São Paulo: Noeses, 2014. p. 3: "A teoria clássica da divisão dos poderes, construída com um claro acento anti-
} 
“neutralização política do Judiciário", sustenta Tércio Sampaio Ferraz Jr., "foi uma das peças mais importantes para o aparecimento de uma nova forma de saber jurídico: a ciência do direito - positivo - no século XIX"16.

Para o intento dar certo, a produção do Direito foi canalizada para o Parlamento, resultando justamente daí o lugar privilegiado das leis enquanto fontes primárias do direito ${ }^{17}$. Só que isso quebraria toda a lógica jurídica vigente.

Alçada como fonte principal do direito, a lei - assim entendida a deliberação parlamentar - inverteu a concepção deste enquanto algo relativamente estável, a despeito das mudanças ocorridas no mundo. Em seu lugar, assumiu a ideia de mutabilidade: tudo poderia ser alterado se o status quo não mais agradasse as forças políticas de cada dado momento ${ }^{18}$.

Daí o motivo de Tércio Sampaio Ferraz Jr. asseverar que a "institucionalização cultural da mutabilidade do direito corresponderá ao chamado fenômeno da positivação do direito"19.

Nesse contexto, o Poder Judiciário era reduzido a mero replicador da lei, com reduzida capacidade institucional no tocante à produção do direito. A Constituição francesa de 1791 , em seu artigo $3^{\circ}$,-cap. V, verbi gratia, dispunha: "Os tribunais não podem se imiscuir no exercício do poder legislativo, nem suspender a execução das leis"20.

Sucintamente, pode-se dizer que o positivismo é uma postura científica que se consolida no século XIX. Mais especificamente quanto

-hierarquizante em face da concepção personalista anterior, iria garantir de certa forma uma progressiva separação entre política e direito, regulando a legitimidade da influência da política na administração, que se torna totalmente aceitável no Poder Legislativo, parcialmente, no Poder Executivo, fortemente neutralizada no Poder Judiciário, tudo dentro dos quadros ideológicos do Estado de Direito".

${ }^{16}$ Idem.

${ }^{17}$ FERRAZ JUNIOR, Tércio Sampaio. op. cit., p. 3-4.

${ }^{18}$ Idem, p. 4: "A concepção da lei como principal fonte do direito chamaria a atenção para a possibilidade de o direito mudar toda vez que mudasse a legislação positiva. Destarte, em comparação com o passado, o direito deixava de ser um ponto de vista em nome do qual as mudanças e as transformações eram aceitas ou rechaçadas. Em todos os tempos, o direito sempre fora percebido como algo estável em face das mudanças do mundo, fosse o fundamento dessa estabilidade a tradição, como para os romanos, a revelação divina, na Idade Média, ou a razão na Era Moderna. Para a consciência social do século XIX, a mutabilidade do direito passa a ser a percepção usual: a ideia de que, em princípio, todo direito muda, torna-se regra, e que algum direito não muda, a exceção".

${ }^{19}$ Idem.

${ }^{20}$ FERRAZ JUNIOR, Tércio Sampaio. op. cit., p. 3. 
ao Direito, Lenio Streck, em rápida passagem, sintetiza a sua expansão no domínio europeu:

No âmbito do direito, essa mensurabilidade positivista será encontrada num primeiro momento no produto do parlamento, ou seja, nas leis, mais especificamente, num determinado tipo de lei: os Códigos. É preciso destacar que esse legalismo apresenta notas distintas, na medida em que se olha esse fenômeno numa determinada tradição jurídica (como exemplo, podemos nos referir: ao positivismo inglês, de cunho utilitarista; ao positivismo francês, onde predomina um exegetismo da legislação; e ao alemão, no interior do qual é possível perceber o florescimento do chamado formalismo conceitual que se encontra na raiz da chamada jurisprudência dos conceitos). No que tange às experiências francesas e alemãs, isso pode ser debitado à forte influência que o direito romano exerceu na formação de seus respectivos direito privado. Não em virtude do que comumente se pensa - de que os romanos "criaram as leis escritas" -, mas sim, em virtude do modo como o direito romano era estudado e ensinado. Isso que se chama de exegetismo tem sua origem aí: havia um texto específico em torno do qual giravam os mais sofisticados estudos sobre o direito. Este texto era - no período pré-codificação - o Corpus Juris Civilis. A codificação efetua a seguinte "marcha": antes dos códigos, havia uma espécie de função complementar atribuída ao Direito Romano. A ideia era simples, aquilo que não poderia ser resolvido pelo Direito Comum, seria resolvido segundo critérios oriundos da autoridade dos estudos sobre o Direito Romano - dos comentadores ou glosadores. O movimento codificador incorpora, de alguma forma, todas as discussões romanísticas e acaba "criando" um novo dado: o Código Civil (França, 1804, e Alemanha, 1900)²1.

Este período é chamado de positivismo exegético (ou primevo) ${ }^{22}$ ou positivismo legalista ${ }^{23}$. Buscava-se eliminar todo o direito antecedente. Criou-se uma verdadeira aversão ao historicismo, na perspectiva de que os códigos seriam início, meio e fim da análise e interpretação de dada matéria ${ }^{24}$.

${ }^{21}$ STRECK, Lenio Luiz. O que é isto: decido conforme minha consciência? 2. ed. Porto Alegre: Livraria do Advogado, 2010. p. 84.

${ }^{22}$ Ibidem, p. 85.

${ }^{23}$ NEVES, Antonio Castanheira. Metodologia jurídica: problemas fundamentais. Coimbra: Coimbra Editora, 1993.

${ }^{24}$ MACÊDO, Lucas Buril de. Precedentes judiciais e o direito processual civil. Salvador: Juspodivm, 2015. p. 36. 
Mas já então se percebeu que as disposições dos Códigos não seriam capazes de cobrir a realidade como um todo ${ }^{25}$. Sua denominação se deve justamente à forma como seus idealizadores chegaram para dar cobro ao problema da interpretação em casos não contemplados pelo sistema analítico-descritivo de regras codificadas ${ }^{26}$.

A ideia era basicamente a análise sintática proposta por Rudolf Carnap ${ }^{27}$. Segundo Lenio Streck, "a simples determinação rigorosa da conexão lógica dos signos que compõem a 'obra sagrada' (Código) seria o suficiente para resolver o problema da interpretação do direito" 28 . Informa ainda o autor que a analogia e os princípios gerais do direito seriam utilizados apenas e tão somente em contextos extremamente excepcionais.

Os exegetas foram ameaçados no começo do século XX, intensificando-se tal ameaça nas décadas de 30 e 40, com o crescimento do poder regulatório do Estado que redundou na insuficiência do rigor do método vigente. Assim, ganhavam espaço a Jurisprudência dos Interesses e a Escola do Direito Livre, "que favoreciam, sobremedida, o aparecimento de argumentos psicológicos, políticos e ideológicos na interpretação do direito" 29 .

Hans Kelsen surgiu no período que então ficou conhecido como positivismo normativista. Sua missão foi a de "reforçar o método analítico proposto pelos conceitualistas de modo a responder ao crescente desfalecimento do rigor jurídico" 30 defendido pelas já referidas Jurisprudências dos Interesses e Escola do Direito Livre. Kelsen chegou à constatação de que o problema do direito era muito mais semântico do que sintático. Daí a ênfase de Hans Kelsen na semântica.

\footnotetext{
${ }^{25}$ Segundo Lucas Buril de Macêdo [op. cit., p. 37], a aversão se estendia aos próprios juristas, a ponto de tentarem torná-los desnecessários, o que, segundo avalia, seria "uma grande utopia".

${ }^{26}$ MACÊDO, Lucas Buril de. op. cit., p. 37: "Os códigos buscam a completude, ou seja, partem da retórica de que todas as soluções já estavam neles contidas, o que não daria espaço nenhum para a criação judicial do direito: assim, o legislador faria o direito no âmbito político e o judiciário simplesmente o aplicaria tecnicamente".

${ }^{27}$ STRECK, Lenio Luiz. O que é isto: decido conforme minha consciência? 2. ed. Porto Alegre: Livraria do Advogado, 2010. p. 85.

${ }^{28}$ Ibidem.

${ }^{29}$ Ibidem, p. 86.

${ }^{30}$ Ibidem.
} 
Kelsen compreendeu a abertura semântica das regras jurídicas como aptas a produzir, tomando como ponto de partida uma mesma disposição, múltiplas normas, as quais se situam no interior do que o autor chama de "moldura da norma", isto é, o conjunto dos sentidos possíveis de uma norma jurídica ${ }^{31}$.

À ciência do Direito cumpre traçar essa moldura, não lhe cabendo optar por esse ou aquele sentido, o que escapa à seara científica jurídica e mergulha nos confins da política. A essa interpretação, Kelsen dá o nome de interpretação não autêntica ou não vinculante, o que acabará se tornando, como se verá, o seu próprio calcanhar de Aquiles $^{32}$.

Anos mais tarde, perceber-se-ia que isso tudo causaria uma profunda reviravolta na concepção do direito, o qual deixaria de ser uma prudência prática para uma técnica poiética. Isto é, o direito deixaria de ser sabedoria, experiências imemoriais, para se tornar uma técnica de experimentação: "domínio do futuro mediante manipulação da experiência como um dado disponível"33.

E, em assim sendo, o direito passa a exigir uma nova técnica ${ }^{34}$, um know-how, um saber-fazer, para que o resultado político do positivismo fosse obtido $^{35}$. No centro desse novo saber, estava a lei:

No sentido sociológico, positivação é, portanto, um fenômeno que no século XIX será representado pela crescente importância da lei votada pelos parlamentos como fonte do direito, em detrimento do costume, da norma costumeira, mas, também, pela sua decrescente importância como bem durável. É que o ancien régime caracterizara-se pelo enfraquecimento da Justiça, cuja dependência política projeta-

\footnotetext{
${ }^{31}$ CATTONI DE OLIVEIRA, Marcelo Andrade. Direito Processual Constitucional. Belo Horizonte: Mandamentos, 2001. p. 40.

${ }^{32}$ STRECK, Lenio Luiz. Precedentes judiciais e hermenêutica: o sentido da vinculação no CPC/2015. Salvador: Juspodivm, 2018. p. 106: “(...) a sentença-decisão é um ato de vontade. Como sabemos, em Kelsen essa é a parte ruim. Essa é a parte em que Kelsen é um realista do Direito: o direito, ao fim e ao cabo, é o que o juiz-tribunal diz que é, porque a decisão é Direito".

${ }^{33}$ FERRAZ JUNIOR, Tércio Sampaio. op. cit., p. 5.

${ }^{34}$ STRECK, Lenio Luiz. O que é isto: decido conforme minha consciência? 2. ed. Porto Alegre: Livraria do Advogado, 2010. p. 63: "Por certo, a pretensão das teorias positivistas era oferecer à comunidade jurídica um objeto e um método seguro para produção do conhecimento científico no direito".
}

${ }^{35}$ FERRAZ JUNIOR, Tércio Sampaio. op. cit., p. 5. 
va-se no arbítrio das decisões. A crítica elaborada pelos pensadores iluministas e a necessidade de segurança da sociedade burguesa passaram, então, a exigir a valorização dos preceitos legais no julgamento dos fatos. Daí se originou um respeito quase mítico pela lei, base, então, para o desenvolvimento da poderosa École de l'Exegése, de grande influência nos países em que dominou o espírito napoleônico. A redução do jurídico ao legal foi crescendo durante o século XIX, até culminar no chamado legalismo ${ }^{36}$.

Nesse contexto, as teorias positivistas do direito estabeleceram uma premissa: "o direito, a partir de então, deveria ser visto como um objeto que seria analisado segundo critérios de uma lógica formal rígida" ${ }^{37}$. Operou-se, portanto, uma cisão entre validade e legitimidade do direito, sendo que a primeira seria resolvida por intermédio de uma "análise lógico-semântica dos enunciados jurídicos" $" 38$, ficando a segunda - que no fundo envolve uma problemática moral - relegada para o campo da teoria política.

Assim, "o positivismo atinge seu desiderato - repito, nas suas mais diversas manifestações - quando consegue descolar a enunciação da lei do mundo concreto, ou seja, quando transforma a lei em uma razão autônoma"39-40. Daí a razão de Tércio Sampaio Ferraz Júnior asseverar que o "direito, com a Revolução Francesa, torna-se, pois, uma criação $a b$ ovo" ${ }^{41}$.

Essa questão teve em Hans Kelsen o seu corifeu, para quem a vinculação do direito à moral se revelava problemática, dada a impossibilidade de sustentar uma moral absoluta ${ }^{42}$. Logo, como havia várias percepções

\footnotetext{
${ }^{36}$ FERRAZ JUNIOR, Tércio Sampaio. op. cit., p. 6.

${ }^{37}$ STRECK, Lenio Luiz. O que é isto: decido conforme minha consciência? 2. ed. Porto Alegre: Livraria do Advogado, 2010. p. 63.

${ }^{38}$ Ibidem.

${ }^{39}$ Ibidem.

${ }^{40}$ Ibidem. p. 64: "Essa racionalidade teórica (ou razão autônoma) possibilitou - e continua a possibilitar - "entender" o direito em sua "autônoma objetividade". Ou ainda em outras palavras, os fatos sociais, os conflitos, enfim, a facticidade, não faziam parte das "preocupações" da teoria do direito. Portanto, ironicamente, a pretensão estabilizadora - e cientificizante - do positivismo jurídico acabou por criar uma babel resultando da separação produzida entre questões teóricas e questões práticas, entre validade e legitimidade, entre teoria do direito e teoria política".

${ }^{41}$ FERRAZ JUNIOR, Tércio Sampaio. op. cit., p. 5.

${ }^{42}$ KELSEN, Hans. Teoria Pura do Direito. 7. ed. São Paulo: Martins Fontes, 2006. p. 74: "O que é importante, porém - o que tem de ser sempre acentuado e nunca o será suficientemente - é a ideia
} 
morais, seria impossível elencar um conceito que servisse como parâmetro seguro da determinação dos conteúdos morais das regras jurídicas.

Para Lenio Streck, "Kelsen estava convicto de que não era possível fazer ciência sobre uma casuística razão prática" ${ }^{\text {"3 }}$. Só importavam ao positivismo, portanto, aspectos formais da ciência do direito, o que, ressalta-se novamente, acabou por se tornar o seu calcanhar de Aquiles ${ }^{44}$.

Isso por que, ao assim proceder, as teorias positivistas colocaram em segundo plano o papel da interpretação/aplicação do direito, relegando aos magistrados, nas chamadas zonas de penumbra ${ }^{45}$ ou nas lacunas legais ${ }^{46}$, a discricionariedade ${ }^{47}$ - a razão maior da insegurança jurídica ${ }^{48}$.

de que não há uma única Moral, 'a' Moral, mas vários sistemas de Moral profundamente diferentes entre os outros e muitas vezes antagônicos".

${ }^{43}$ STRECK, Lenio Luiz. O que é isto: decido conforme minha consciência? 2. ed. Porto Alegre: Livraria do Advogado, 2010. p. 64.

${ }^{44}$ Ibidem, p. 65: “(...) há um ponto que marca definitivamente o equívoco cometido por todo o positivismo ao apostar em certo arbitrio (eufemisticamente epitetado como 'discricionariedade') do julgador no momento de determinar sua decisão: sendo o ato jurisdicional um ato de vontade, ele representa uma manifestação da razão prática, ficando fora das possibilidades do conhecimento teórico. Isso ainda não foi devidamente entendido pela(s) teoria(s) do direito. Não é fácil, pois, derrotar o positivismo...".

${ }^{45}$ A esse propósito, Lenio Streck [In $\mathbf{O}$ que é isto: decido conforme minha consciência? 2. ed. Porto Alegre: Livraria do Advogado, 2010. p. 68] registra: "Até mesmo um positivista considerado moderado como Hart - este epíteto lhe foi dado por Dworkin -, ao tratar da textura aberta, procura resolver os casos dificeis (hard cases) através da interpretação das zonas de penumbra (textura aberta) da norma. Também ali não há lugar para os princípios (volta-se sempre para a contraposição 'discursos de fundamentação-discursos de aplicação'). Abre-se, assim, a possibilidade da discricionariedade do intérprete. Afinal, se a tese hartiana da zona da penumbra (vagueza e ambiguidade da norma) é atrativa, também é verdade que ela não se resolverá na aplicação, mas, sim, no campo da conceitualização. Só que isso deixa a interpretação do direito insulado na velha razão teórica".

${ }^{46}$ Ao criticar o positivismo, Lenio Streck expõe em continuação [op. cit., p. 68-69]: “(...) diante das insuficiências/limitações das regras, diante dos 'casos dificeis' e face à pluralidade de regras ou sentidos da(s) regra(as), o positivismo permite que o juizfaça a 'melhor escolha'. O direito é, assim, apenas a moldura na qual serão subsumidos os 'fatos' (como se fosse possivel separar fato e direito)".

47 "Kelsen já havia superado o positivismo exegético, mas abandonou o principal problema do direito: a interpretação concreta, no nível da 'aplicação'. E nisso reside a 'maldição' de sua tese. Não foi bem entendido, quando ainda hoje se pensa que, para ele, o juiz deve fazer uma interpretação "pura da lei"”. (STRECK, Lenio Luiz. O que é isto: decido conforme minha consciência? 2. ed. Porto Alegre: Livraria do Advogado, 2010. p. 87).

${ }^{48}$ MAUS, Ingeborg. Judiciário como superego da sociedade: o papel da atividade jurisprudencial na "sociedade órfã”. Revista Novos Estudos CEBRAP, São Paulo, n. 58, p. 183-202, nov. 2000. p. 189-190: "Toda menção a um dos princípios 'superiores' ao direito escrito leva quando a Justiça os invoca - à suspensão das disposições normativas individuais e a se decidir o caso concreto 
Como já se demonstrou, nenhum sistema de normas consegue abarcar todas as hipóteses fáticas ${ }^{49}$. E isso é natural. Todavia, a forma como os positivistas lidaram com a incompletude acabou por gerar uma contradição interna insuperável de sua própria teoria positivista: o subjetivismo do intérprete se sobrepõe à objetividade do sistema normativo ${ }^{50}$.

A título ilustrativo, cabe mencionar a inconstitucionalidade declarada pelo Tribunal Superior Eleitoral ao instituto processual dos prejulgados, previsto no artigo 263 do Código Eleitoral.

Diz o Código: “Art. 263. No julgamento de um mesmo pleito eleitoral, as decisões anteriores sobre questões de direito constituem prejulgados para os demais casos, salvo se contra a tese votarem dois terços dos membros do Tribunal".

Ao tê-lo por inconstitucional, o Tribunal Superior Eleitoral, no julgamento do Recurso nº 9.936/RJ, acompanhou à unanimidade o voto do Relator, Ministro Sepúlveda Pertence, que, a propósito do tema, assim se manifestou - verbis:

Senhor Presidente, refleti sobre o tema e acabei me convencendo da inconstitucionalidade. É óbvio que a hipótese é um pouco diversa da do prejulgado trabalhista que é significativamente mais rígido; primeiro porque o trabalhista se impunha diretamente aos órgãos inferiores da estrutura da Justiça do Trabalho, enquanto o prejulgado eleitoral tem eficácia restrita a cada Tribunal; no tempo, enquanto o

de forma inusitada. Assim, enriquecido por pontos de vista morais, o âmbito das 'proibições' legais pode ser arbitrariamente estendido ao campo extrajurídico das esferas de liberdade. Somente a posteriori, por ocasião de um processo legal, é que o cidadão experimenta o que lhe foi 'proibido', aprendendo a deduzir para o futuro o 'permitido' (extremamente incerto) a partir das decisões dos tribunais. Os espaços de liberdade anteriores dos indivíduos se transformam então em produtos de decisão judicial fixados caso a caso".

49 "A impossibilidade de previsão, nas leis escritas, das soluções dos casos ou dos problemas concretos deriva, na essencialidade de sua longa história, de que os atos humanos, as condutas das pessoas e as surpresas de suas relações sociais são completamente rebeldes a tratamentos apriorísticos ou generalistas, precisamente porque decorrem de manifestações subjetivas irrepetíveis e subjetivamente variáveis de uma para outra pessoa, ou seja, são sempre contextuais". (MAIA FILHO, Napoleão Nunes. Princípios jurídicos e garantismo judicial: atitude antipositivista e jurisdição includente. Fortaleza: Imprece, 2016. p. 198).

${ }^{50}$ STRECK, Lenio Luiz. O que é isto: decido conforme minha consciência? 2. ed. Porto Alegre: Livraria do Advogado, 2010. p. 69: "E esse saber operacional permanece calcado exatamente na 'hipótese positivista' ou 'fator discricionário': quando a razão teórica não consegue responder todas as perguntas - que, abstratamente, são feitas antes da aplicação, porque ainda cindem interpretação-aplicação -, delega-se o poder de 'colmatar o sistema', paradoxalmente, àquilo que o positivismo queria 'isolar', à razão prática, que, como sabemos, vem 'eivada' de subjetividade". 
prejulgado trabalhista é de duração indeterminada, o eleitoral só vige no mesmo período eleitoral em que assentado.

Dois, porém, são os pontos em que me parece haver o choque com a Constituição.

O primeiro é idêntico ao do prejulgado trabalhista. Apesar das diferenças notadas, a menor extensão orgânica, a temporariedade e a maior flexibilidade - porque ainda neste período se permite a revisão por um quórum qualificado - o que é certo e que também o prejulgado trabalhista faz de um precedente jurisprudencial como norma vinculante da decisão do Tribunal. Logo, dá ao precedente judicial força de lei, o que viola o princípio de separação funcional aos poderes. O exemplo que estamos vivendo é manifesto: o Tribunal, em sua composição plenária, por maioria absoluta, se manifesta no sentido de conhecer de determinado recurso, mas a aplicação da regra do prejulgado levaria, não obstante, a proclamar que o recurso não fora conhecido. E a minuta teria de consignar: "não conhecido por maioria de voto." Aqui está à prova de que se sobrepõe, a independência jurídica dos juízes, que, nos colegiados, por maioria, compõem a decisão do Tribunal, se sobrepõe um precedente de jurisprudência.

Anoto mais, Senhor Presidente, que o Tribunal, de certo modo, já se antecipou à condenação do prejulgado. Nossa recente emenda regimental adota expressamente o mecanismo da súmula, e a ideia de súmula é incompatível com a ideia de prejulgado. A súmula é apenas - tivemos oportunidade de dizer, o eminente Ministro Carlos Velloso, Relator e eu, no voto - vista, na decisão da Ação Direta n9 594, que a súmula é uma forma de proclamação solene, um instrumento de relativa estabilidade da jurisprudência, que não pretende, jamais, impor ao Tribunal a proclamação de uma decisão contra a convicção de sua maioria. Apenas quer que esta mudança de jurisprudência seja consciente; este é o grande propósito da súmula, estabelecer um procedimento de mudança da jurisprudência, sem nenhum quórum qualificado. A grande revolução da súmula foi tentar pôr fim à jurisprudência lotérica, à decisão lotérica, às mudanças inconscientes do entendimento do Tribunal. Mas, uma vez posta conscientemente a questão, uma súmula não constitui nenhuma limitação à afirmação da independência jurídica e da convicção de cada juiz sobre a tese jurídica posta.

Ocorre-me, afinal, mais uma consideração. É tão violenta a força vinculante que o prejulgado pretende, que ele é maior do que a força obrigatória da lei. Veja V. Exa.: se nesta votação, tivermos qua- tro votos pela inconstitucionalidade de uma lei, podemos deixar de 
aplicá-la; mas teríamos que ter cinco votos para deixar de aplicar o critério de um precedente que, ao ver da maioria do Tribunal, não interpretou bem a lei.

De tal modo, Senhor Presidente, que meu voto incidentemente declara inconstitucional o art. 263 desde a Constituição de 46, sob a qual foi editado ${ }^{51}$.

Assim se deu o julgamento, é óbvio, porque o raciocínio positivista que imperava à época tinha por inconcebível que um Tribunal ficasse vinculado às próprias decisões, sendo que, atualmente, é o contrário que causa espanto.

De todo modo, pode-se verificar que é o livre convencimento (decido conforme e somente conforme a minha própria consciência), próprio do positivismo então vigente, ainda que não explicitado na decisão, o fundamento de relevo para se afastar a validade do instituto do prejulgado, como pode se extrair do seguinte excerto do voto alhures transcrito: "uma súmula não constitui nenhuma limitação à afirmação da independência jurídica e da convicção de cada juiz sobre a tese jurídica posta" ${ }^{52}$.

Nesse mesmo sentido, voltou a decidir o Tribunal Superior Eleitoral em 21 de março de 1996, ou seja, 4 (quatro) anos depois, reafirmando-se o entendimento de que o prejulgado é incompatível com a Constituição Federal por "estabelecer o efeito vinculante" 53 .

Daí porque o intérprete, no atual estágio normativo, e levando-se em consideração a perspectiva do positivismo, sai da qualidade de escravo da lei para uma posição sobranceira no sistema, sem qualquer amarra à sua decisão que não seja o seu convencimento sobre a interpretação da lei,

${ }^{51}$ BRASIL. Tribunal Superior Eleitoral. Recurso no 9.936 - Classe $4^{\text {a }}$ - Nova Friburgo - RJ. Recurso especial: regularidade da apresentação do partido político pelo Diretório Municipal na sua interposição [...]. Relatora: Min. Sepúlveda Pertence, acórdão de 14 de setembro de 1992. Disponível em: http://www.tse.jus.br/jurisprudencia/decisoes/jurisprudencia. Acesso em: 12 jan. 2019.

${ }^{52}$ Idem.

${ }^{53}$ BRASIL. Tribunal Superior Eleitoral. Embargos de Declaração no Recurso Especial Eleitoral no. 12.082 - Goiás (Anápolis). Embargos declaratórios. Omissão. Contradição. Exsurgindo do acórdão proferido qualquer dos vínculos suficientes a impulsionar os declaratórios - omissão, contradição e obscuridade - impõe-se-lhes o acolhimento [...]. Relator: Min. Marco Aurélio, acórdão de 21 de março de 1996. Disponível em: http://www. tse.jus.br/jurisprudencia/decisoes/jurisprudencia. Acesso em: 12 jan. 2019. 


\title{
sobremodo no atual estágio em que, por conta da própria evolução social, as normas tendem a ter a textura mais aberta ${ }^{54}$, dado o dinamismo do mundo ${ }^{55}$.
}

\author{
${ }^{54}$ É esse o caso de algumas das hipóteses (alíneas "g" e "l", para ser mais preciso) de \\ inelegibilidade advindas com a Lei Complementar $n^{\circ}$. 135/2010, que transferem ao Juiz \\ Eleitoral a possibilidade de significação de seus conteúdos vagos, causando insegurança \\ jurídica.
}

${ }^{55}$ Por todos, FARIA, José Eduardo. Sociologia jurídica: direito e conjuntura. 2. ed. SãoPaulo: Saraiva, 2010. p. 45-6: “Após os conhecidos processos de 'publicização do direito privado' $e$ subsequente 'administrativização do direito público' ocorridos no âmbito do Welfare State entre o final dos anos 40 e início dos anos 70, o que se tem a partir das décadas de 80 e 90 é um ordenamento jurídico à primeira vista cada vez mais fragmentado - ou seja, sem unidade lógica, sem coerência programática e sem rigor conceitual. Portanto, um ordenamento incapaz de abarcar as incertezas do sistema social, de conter e prover a solução de todos os problemas jurídicos, de filtrar, absorver e regular novos tipos de conflito, de assegurar calculabilidade e previsibilidade das condutas sociais e de dar conta da emergência de novas categorias de atores econômicos, sociais e políticos, que abalaram o monopólio que os Estados detinham, quer em relações locais, quer em relações internacionais. Na medida em que muitos desses problemas são equacionados por normatividades paralelas ou justapostas, pois uma parte significativa das atividades econômicas transnacionais fica fora do alcance dos tradicionais instrumentos de controle e gestão do Estado-nação, o ordenamento jurídico estatal tende a perder sua centralidade e, acima de tudo, sua exclusividade. Ainda que continue permanecendo como referência básica para os cidadãos comuns, na prática ele passa a sofrer a concorrência de outras orientações, identidades, determinações e formas de gestão. Com isso, deixa de ser o eixo de um sistema normativo único, com feições basicamente piramidais e assentado num conjunto hierarquizado de regras subordinantes (top-down control), para se tornar parte de um polissistema (multi-level system), com suas formas e categorias públicas, privadas e híbridas; ao mesmo tempo, deixa também de ser a fonte de legitimidade de uma ordem jurídica autocentrada nos estritos limites de um território (Canotilho, 1998 e 2006-b; Moreira, 2001; Sand, 2002 e 2004; Sassen, 2004; e Picciotto, 2007) e passa a abrir-se progressivamente a normas oriundas de organismos multilaterais, de centros regionais e de poderes locais, bem como de agentes de mercado que, valendo-se de seu poder econômico e financeiro, transformam faticidade em normatividade e disputam com o Estado o monopólio da produção do direito (Santos, 1996, 1999 e 2001). A exemplo do próprio Estado-nação, que nesse cenário vai deixando de ser um ator exclusivo e privilegiado para se converter num marco a mais entre tantos outros nas negociações econômicas, políticas e sociais, e cujo poder real em muitos casos só lhe permite adequar-se a um quadro que em muito o transcende, esse ordenamento é constituído como mais um sistema normativo, entre vários outros igualmente válidos. Do ponto de vista de sua arquitetura interior, esse ordenamento se destaca por sua legislação basicamente "descodificada", formada pela multiplicação desenfreada de leis especiais sobre matérias cada vez mais técnicas e específicas nos planos cível, societário, falimentar, econômico, tributário, fiscal, administrativo, previdenci-ário, sindical, trabalhista, de segurança social, penal, ambiental etc. Expressando-se sob a forma de uma combinatória de normas de organização, normas de conduta, normas programáticas ou principiológicas, cláusulas gerais e conceitos indeterminados, essas leis especiais, intercruzando-se continuamente, terminam produzindo inúmeros microssistemas e distintas cadeias normativas no âmbito do direito positivo. Assumindo assim a forma de redes, esses inúmeros microssistemas legais e essas distintas cadeias normativas se caracterizam pela extrema multiplicidade, variedade e heterogeneidade de suas regras e de seus mecanismos processuais; pela evidente provisoriedade e mutabilidade de suas engrenagens normativas, uma vez que as regras já não são mais relativamente estáveis, modificando-se no curso da partida; pela tentativa de acolhi- 
O referido fenômeno normativo, que muda a compreensão do Direito enquanto sistema codificado para um sistema de normas abertas ${ }^{56}$, causa uma verdadeira revolução ${ }^{57}$, um verdadeiro tsunami nas ciências jurídicas, sobretudo quando os juristas ainda laboram com o antigo método interpretativo do positivismo, teoria que se sedimentou na ideia de um sistema de normas analíticas.

No ponto, cabe registrar a doutrina de Roberto Freitas Filho:

Há, no discurso sobre o direito, a reiteração de que houve uma mudança na forma de legiferar, no sentido da modificação da técnica legislativa pela introdução das cláusulas gerais, dos conceitos jurídicos indeterminados e dos princípios, tendo a mudança ocorrido em função das normas permitirem uma maior mobilidade do aplicador para que sejam implementadas políticas e sejam-nas subsumidos fatos que se modificam na sua expressão concreta do dia a dia, permitindo que haja uma aplicação prospectiva. Há, dessa forma, a preservação da norma enquanto tal e, ao mesmo tempo, sua aplicabilidade a novas formas de relação que não foram previstas quando do momento da positivação $^{58}$.

mento de uma pluralidade de pretensões contraditórias e, na maioria das vezes, excludentes; pela geração de conflitos e discussões extremamente complexas, em matéria de hermenêutica, exigindo dos operadores e dos intérpretes conhecimentos especializados não apenas no âmbito do direito positivo, mas, igualmente, nos planos da macroeconomia, da engenharia financeira, da contabilidade, das técnicas de auditoria e compliance, das ciências atuariais, da tecnologia de comunicações, da informática, da análise de risco sistêmico etc".

${ }^{56}$ Sobre a utilização de conceitos jurídicos indeterminados no Direito Eleitoral, confira-se, dentre outros, DUARTE, Michelle Pimentel. Processo judicial eleitoral: jurisdição e fundamentos para uma Teoria Geral do Processo Judicial Eleitoral. Curitiba: Juruá, 2016. p. 109-114.

${ }^{57}$ Ao analisar o Direito na atualidade, François Ost registra: "jamás se ha hablado tanto como hoy de los princípios generales del Derecho, gracias especialmente al trabajo creativo de las altas jurisdicciones nacionales y europeas" (OST, François. Júpiter, Hércules, Hermes: tres modelos de juez. Revista sobre enseñanza del Derecho, Buenos Aires, n. 8, p. 101-130, 2007. p. 121).

${ }^{58}$ FREITAS FILHO, Roberto. Intervenção judicial nos contratos e a aplicação dos princípios e das cláusulas gerais: o caso leasing. Porto Alegre: Sérgio Antônio Fabris Editor, 2009. p. 28. 
Sem nenhuma amarra, o magistrado, nesse sistema que foi criado para contê-lo, assenhorou-se do Direito. Isso não podia (ou não pode...) continuar assim ${ }^{59}$.

\section{O papel da interpretação/aplicação do direito no atual estágio jurídico do pós-po itizsi mo jurídico}

A ideia geral e centenária da subsunção positivista (que apregoava as plenas autonomia e objetividade do direito ${ }^{60}$ ) - aquela que sustentava a premissa do juiz como mero replicador da lei; a magistratura como reduzida "a boca da lei" ${ }^{61}$; pappagallo dela legge $e^{62}$ (papagaio da lei) - morreu. Como já previamente registrado neste trabalho, não há mais como o jurista do século XXI ignorar a função criadora ${ }^{63}$ da interpretação/aplicação judicial do direito $^{64-65}$

\footnotetext{
${ }^{59}$ Ibidem, p. 28-9: "O pressuposto do argumento é que a construção da decisão na qual se aplicam normas abertas é diferente daquela na qual se aplicam normas casuisticas, as quais chamo de 'normas fechadas'. A diferença não está em que se proceda ou não por dedução no momento de decidir, já que neste particular qualquer decisão segue necessariamente ao procedimento silogístico. O que há de diferente na aplicação das normas abertas é que o sentido descrito da norma não está expresso a priori em seu texto, ou seja, é necessário que o aplicador venha a especificar os elementos que compõem a regra na ratio decidendi da decisão".
}

${ }^{60}$ POSNER, Richard A. Problemas de filosofia do direito. Tradução de Jefferson Luiz Camargo. São Paulo: Martins Fontes, 2007. p. 612: "Em nossa época pluralista e científica, as tentativas de voltar a ter confiança na autonomia e objetividade do direito parecem fúteis".

${ }_{61}$ "Os juízes de uma nação não são, como dissemos, mais do que a boca que pronuncia as sentenças da lei, seres inanimados que não podem moderar sua força nem seu rigor". (MONTESQUIEU. 0 espírito das leis. 2. ed. Brasília, DF: UNB, 1995. v. 6. p. 123).

${ }^{62}$ ZAGREBELSKY, Gustavo; BRUNELO, Mario. Interpretare: dialogo tra un musicista e un giurista. Milano: Società editrice il Mulino, 2016. p. 52.

${ }^{63}$ Em sua experiência como magistrado nos Estados Unidos da América, Benjamin Cardozo (op. cit., p. 122) diz que, em uma parcela dos casos, "a decisão num ou noutro sentido será levada em conta no futuro e poderá avançar ou retardar, ora muito, ora pouco, o desenvolvimento do Direito. São esses os casos em que o elemento criativo do processo judicial encontra sua oportunidade e potencialidade". Em seguida, o autor (op. cit., p. 123) arremata: "É aqui que o juiz assume a função de legislador". É preciso ter em mente que isso fora dito na década de 30 do século passado.

${ }^{64}$ BARCELLOS, Ana Paula de. Direito e política. Silêncio do legislador, interpretação e analogia. In: SARMENTO, Daniel (coord.). Jurisdição Constitucional e Política. Rio de Janeiro: Forense, 2015. p. 661.

65 “A lei vincula seus destinatários, não seus intérpretes". (ADOMEIT, Klaus. Juristische Metho- de. In: GÖRLITZ, Axel (ed.). Handlexikon zur Rechtswissenschaft. München: Ehrenwir- 
Aliás, o raciocínio não é de hoje. Já para Larenz, sustentar que “o processo de uma dedução da maior parte das decisões a partir da lei por meio da subsunção lógica (da situação do fato sob a previsão de uma norma legal) ou é geralmente inadequado ou então só lhe reconhecem um significado mínimo"66.

Como se vê, o fascínio pela subsunção/silogismo e a ideia da lei como fonte formal única do Direito parecem ser mesmo fruto da transmissão irrefletida das ciências jurídicas, em especial no Brasil contemporâneo.

Mas havia exceções. Por todos, urge rememorar e fazer justiça aos escritos de Francisco Cavalcanti Pontes de Miranda:

(...) O princípio de que o juiz está sujeito à lei é, ainda onde o meteram nas Constituições, algo de 'guia de viajantes', de itinerário, que muito serve, mas nem sempre basta. (...) Se entendermos que a palavra 'lei' substitui a que lá deverá estar, 'direito', já muda de figura. Porque o direito é conceito sociológico, a que juiz se subordina, pelo fato mesmo de ser instrumento da realização dele. E esse é o verdadeiro conteúdo do juramento do juiz, quando promete respeitar e assegurar a lei. Se o conteúdo fosse o de impor a letra legal, e só ela, aos fatos, a função judicial não corresponderia àquilo para que foi criada: apaziguar, realizar o direito objetivo. Seria a perfeição em matéria de braço mecânico do legislador, braço sem cabeça, sem inteligência, sem discernimento, mas antissocial e, como a lei e a jurisdição servem à sociedade, absurda. (...) Seria pouco provável a realizabilidade do direito objetivo, se só fosse a lei: não apenas pela inevitabilidade das lacunas, como porque a própria realização supõe provimento aos casos omissos e a subordinação das partes imperfeitas aos princípios do próprio direito a ser realizado ${ }^{67}$.

th, 1972. p. 217-220 apud MAUS, Ingeborg. Judiciário como superego da sociedade: o papel da atividade jurisprudencial na "sociedade órfã". Revista Novos Estudos CEBRAP, São Paulo, n. 58, p. 183-202, nov. 2000. p. 198).

${ }^{66}$ LARENZ, Karl. Metodologia da ciência do direito. Tradução de José Lamego. 3. ed. Lisboa: Fundação Calouste Gulbenkian, 1997. p. 215.

${ }^{67}$ PONTES DE MIRANDA, Francisco Cavalcanti. Comentários ao Código de Proces- so Civil. T. VI. Rio de Janeiro: Forense, 1975, p. 288-292 apud GRAU, Eros Roberto. op. cit., p. 72 . 
Mesmo Kelsen, tido como o pai dos positivistas ${ }^{68}$, nunca apregoou essa visão estreita das fontes do Direito. Ao se referir à moldura como espaço do processo cognitivo do direito, deixava o autor, e isso é inegável, larga margem de atuação ao intérprete final: o juiz. Em seus próprios termos, "(o) direito a aplicar forma (...) uma moldura dentro da qual existem várias possibilidades de aplicação, pelo que é conforme ao Direito todo ato que se mantenha dentro deste quadro ou moldura, que preencha esta moldura em qualquer sentido possível"69.

Mas Kelsen era um positivista-normativista e sustentou tal teoria na metade do século XX. Jamais imaginaria o tamanho da moldura no sis- tema normativo contemporâneo, o qual adota normas abertas, "ou seja, as cláusulas gerais, os conceitos jurídicos indeterminados e os princípios”, os quais demandam do aplicador, com ainda maior razão, "um papel ativo na determinação de seu sentido ao aplicá-las aos casos concretos"70.

E cada preenchimento dessa moldura vai propiciando uma ressignificação ${ }^{71}$ do direito, por intermédio da formação de uma cadeia de precedentes judiciais a propósito de cada norma jurídica ${ }^{72}$. Tal qual ensina José La-

\footnotetext{
${ }^{68}$ Aliás, mesmo os positivistas assim declarados não enxergavam o Direito como fruto da mera legalidade, o que foi difundido durante muito tempo no Brasil de forma equivocada. Por todos, confira-se HART, Herbert Lionel Adolphus. The Concept of Law. Oxford: Oxford University Press, 1994. p. 269 - verbis: "De acordo com minha teoria, a existência e o conteúdo do direito podem ser identificados por meio de referência às fontes sociais do direito (por exemplo, a legislação, as decisões judiciais, os costumes sociais) (...)”.

${ }^{69}$ KELSEN, Hans. Teoria Pura do Direito. (Trad.) João Baptista Machado. 6. ed. São Paulo: Martins Fontes, 2003. p. 390.
}

${ }^{70}$ FREITAS FILHO, Roberto. op. cit., p. 28.

${ }^{71}$ MARINONI, Luiz Guilherme. A Ética dos Precedentes: justificativa do Novo CPC. 2. ed. rev. e atual. São Paulo: Revista dos Tribunais, 2016. p. 106: "Há uma relação de continuidade entre a solução da nova questão e o precedente, conferindo à atividade judicial um modo de pensar que vaise desenvolvendo aos poucos, similar ao raciocínio de um jurista que dá continuidade ao tratamento de umtema que engloba vários ensaios ou livros. A diferença mais saliente é que, no caso dos precedentes, o racio-cínio não é de uma mesma pessoa, mas de juízes que, exatamente porque integram uma instituição, devem admitir, sem contestar, o que já foi definido no precedente, dando prosseguimento ao discurso da Corte para solucionar a nova questão".

${ }^{72}$ Nesse sentido, veja-se a lição de Maurício Ramires. Diálogo Judicial Internacional. Rio de Janeiro: Lumen Juris, 2016. p. 31: “(...) quando alguém interpreta um texto constitucional contemporâneo, ele interpreta simultaneamente a história do constitucionalismo que vem à tona no horizonte do intérprete e o ajuda a situá-lo no espaço e no tempo. Não que o intérprete deva estudar e conhecer em detalhes toda essa história, com o rigor do historiador profissional. Mas deve, isto sim, fazer esforço suficiente para saber e reconhecer que os pilares que sustentam a Constituição em sentido moderno, isto é, 
mego, "o aditamento de sentido que se opera em cada nova interpretação e o carácter 'único' de cada situação são manifestos na hermenêutica jurídica"’3.

Nesse sentido, adverte Humberto Ávila que: "Normas não são textos nem o conjunto deles, mas os sentidos construídos a partir da interpretação sistemática de textos normativos. Daí se afirmar que os dispositivos se constituem no objeto da interpretação; e as normas, no seu resultado" $" 74$.

Embora isso seja factível atualmente, é preciso reconhecer que o momento crucial; decisivo para o reconhecimento dessa visão se deu com o giro linguístico-hermenêutico da filosofia e sua consequente influência no direito ${ }^{75}$.

De forma sucinta, o giro linguístico-hermenêutico alterou o conceito e o fundamento da verdade. Antigamente, como explica Abboud, o conceito de verdade era correspondencial (também chamado paradigma da adequação ou objetivista), isto é, "aquele que acredita ser verdade o produto da correspondência da coisa ao intelecto" "76.

Esse primeiro paradigma, que predominou na antiguidade clássica e na filosofia medieval, sofreu duro golpe na revolução copernicana operada por Kant, a partir da qual se tem um novo conceito de verdade ${ }^{77}$. Ainda com esteio na lição de Abboud, "a verdade passa a ser uma construção subjetiva do sujeito congnoscente, possibilitando-se falar em um conceito subjetivista de verdade "78.

o Estado de direito, a democracia e os direitos fundamentais, não são meras palavras ao vento; são antes conquistas que remontam a muitos séculos de avanços e retrocessos".

${ }^{73}$ LAMEGO, José. Hermenêutica e jurisprudência: análise de uma recepção. Lisboa: Fragmentos, 1990. p. 92.

${ }^{74}$ ÁVILA, Humberto. Teoria dos princípios: da definição à aplicação dos princípios jurídicos. 12. ed. São Paulo: Malheiros Editores, 2011. p. 30.

${ }^{75}$ Por todos, ABBOUD, Georges. Processo constitucional brasileiro. São Paulo: Revista dos Tribunais, 2016. p. 55-102.

${ }^{76}$ Op. cit., p. 66-68.

${ }^{77}$ Ao contrapor o positivismo (representado pelo Juiz Júpiter) e o realismo jurisprudencial (representado pelo Juiz Hércules), para se chegar, então, à sua teoria pluralista do Direito, François Ost indaga: “No es tiempo de pensar el Derecho como circulación incesante de sentido, más que como discurso de la verdad?” (OST, François. Júpiter, Hércules, Hermes: tres modelos de juez. Revista sobre enseñanza del Derecho, Buenos Aires, n. 8, p. 101-130, 2007. p. 114).

${ }^{78}$ Idem. 
A filosofia da linguagem assume papel sobranceiro. A linguagem deixa de ser instrumento para ser elemento constituidor da verdade ${ }^{79}$. Conforme Gadamer, "a linguagem não se posiciona ao lado da arte, do direito e da religião, mas representa o medium sustentador de todos esses fenômenos" $"$.

A sua influência nas ciências jurídicas é bem aquilatada por Castanheira Neves, para o qual

o direito é linguagem, e terá de ser considerado em tudo e por tudo como uma linguagem. $\mathrm{O}$ que quer que seja e como quer que seja, ao que quer que ele se proponha e como quer que nos toque, o direito é-o numa linguagem e como linguagem - propõem-se sê-lo numa linguagem (nas significações linguísticas em que se constitui e se exprime) e atinge-nos através dessa linguagem, que é ${ }^{81}$.

A interpretação jurídica, portanto, deixa de ser um problema estrita e rigorosamente hermenêutico ${ }^{82}$ e passa a ser um problema essencialmente normativo, isto é, "a interpretação jurídica só será entendida em termos metodologicamente correctos se for vista como determinação normativo-pragmaticamente adequada de um critério jurídico do sistema do direito vigente para a solução do caso decidendo"

E conclui Castanheira: "Vimos a resposta que o modelo tradicional dava a esta questão do objecto da interpretação - o objecto da interpretação seria o texto da norma jurídica. E vimos também por que essa

79 "(...) a linguagem passa a ser constituinte e constituidora do mundo do homem”. (ABBOUD, Georges. Processo constitucional brasileiro. São Paulo: Revista dos Tribunais, 2016. p. 71).

${ }^{80}$ GADAMER, Hans-Georg. Verdade e método: traços fundamentais de uma hermenêutica filosófica. 2. ed. Rio de Janeiro: Vozes, 2004. p. 89 apud ABBOUD, Georges. Processo constitucional brasileiro. São Paulo: Revista dos Tribunais, 2016. p. 68.

${ }^{81}$ NEVES, Antonio Castanheira. Metodologia jurídica: problemas fundamentais. Coimbra: Coimbra Editora, 1993. p. 90.

82 "Nos sistemas de civil law há intensa preocupação com a ciência do direito. Busca-se enunciar o direito a partir de conceitos, tais conceitos seriam logicamente inferidos de outros e deles vários novos conceitos poderiam ser deduzidos. O trabalho, até mesmo prático, muitas vezes se limita a operar com conceitos abstratos, negligenciando a facticidade, e por outras tentar elevar o que é feito em um caso concreto a uma conceptualização abstratizada: assim os juristas acabam mais preocupados em encontrar teorias cientificamente aplicáveis do que em resolver problemas práticos com justiça". (MACÊDO, Lucas Buril de. Precedentes judiciais e o direito processual civil. op. cit., p. 42)

${ }^{83}$ NEVES, Antonio Castanheira. op. cit., p. 142. 
resposta não pode manter-se: o problema da interpretação jurídica não é hermenêutico - mas normativo" $"$.

Sobre a temática, Tércio Sampaio Ferraz Júnior, no que chamou de Prefácio de um Posfácio, registrou:

A subsunção é, aos poucos, sobrepujada pela ponderação de princípios, pois os juízes não aplicam apenas a legislação, mas fazem constantes referências aos princípios jurídicos. Antes, os princípios eram invocados para integrar o direito, isto é, apenas nos casos de lacunas (nesse sentido deles fala a nossa Lei de Introdução). Com isso, à primeira vista, parece que o juiz, agora, tem uma liberdade muito maior para reconstruir e até construir o direito, que antes era assumido como um dado. Mesmo porque o rol de princípios admitidos não limita a princípios expressos na legislação ordinária e constitucional, mas são "descobertos" a partir das exigências decisórias. Não que isso não ocorresse no passado. Mas era algo revelado pela doutrina por força de exigências sistematizadoras do material obrigacional contido no ordenamento, e não pela jurisprudência como suporte direto da decisão do caso concreto.

Em consequência, passamos da centralidade da lei para a centralidade da jurisdição, jurisdição entendida em sentido amplo: os tribunais judiciais, tribunais de arbitragem, as agências administrativas com poder judicante (com tribunais e conselhos administrativos), os órgão da administração direta (que dizemo direito por meio de sentenças, acórdãos, decisões interlocutórias, resoluções, pareceres normativos).

Por isso a tensão se desloca do legislador/doutrina dogmática para o juiz/doutrina dogmática. O problema da aplicação, da justificação da decisão jurídica ganha uma importância inédita ${ }^{85}$.

Embora a referida percepção seja aparentemente nova, pelo menos no Brasil, Friedrich Müller, pai da teoria estruturante do Direito, há pelo menos 50 (cinquenta) anos, já criticava o positivismo legalista - verbis:

(...) se evidenciou que o positivismo legalista ainda não superado pela teoria e práxis refletidas, com a sua compreensão do direito como sistema sem lacunas, da decisão como uma subsunção estritamente lógica, e com a sua eliminação de todos os elementos da ordem social

\footnotetext{
${ }^{84}$ Ibidem, p. 143.

${ }^{85}$ FERRAZ JÚNIOR, Tércio Sampaio. O direito, entre o futuro e o passado. São Paulo: Noeses, 2014. p. XV.
} 
não reproduzidos no texto da norma é tributário de uma ficção que não pode ser mantida na prática ${ }^{86}$.

Os enunciados normativos, no atual estágio, não são apenas os atos normativos primários, como ocorria na época do legalismo. Mais que isso, neste grupo incluem-se os precedentes, os quais vão formando, ao longo do tempo, o corpo jurídico íntegro ${ }^{87}$ (romance em cadeia ${ }^{88}$ ) a que faz alusão R. Dworkin, no qual o cidadão deposita confiança ao se planejar para agir.

Nesse sentido, verifique-se a didática lição de Dworkin: "um juiz ou um cidadão que precisa decidir o que é direito quando se vê diante de alguma questão complexa, deve interpretar o direito do passado para descobrir quais os princípios melhor o justificam e, em seguida, decidir o que tais princípios exigem no novo caso" 89 .

A esse propósito, confira-se, uma vez mais, o escólio de F. Müller:

A não identidade de norma e texto da norma, a não vinculação da normatividade a um teor literal fixado e publicado com autoridade, ressalta também do fenômeno do direito consuetudinário. Não se duvida da sua qualidade jurídica, embora ele não apresente nenhum texto definido com autoridade. Essa propriedade do direito, de ter sido elaborado de forma escrita, lavrado e publicado segundo um determinado procedimento ordenado por outras normas, não é idêntica à sua qualidade de norma. Muito pelo contrário, ela é conexa a imperativos do Estado de Direito e da democracia, característicos do Estado constitucional burguês da modernidade. Mesmo onde o direito positivo dessa espécie predominar, existe praeter constitutionem

${ }^{86}$ MÜLLER, Friedrich. Métodos de trabalho do direito constitucional. Porto Alegre: Síntese, 1999. p. 48.

${ }^{87}$ Neste sentido, ABBOUD, Georges. op. cit., p. 77: “(...) a norma é um produto da interpretação, ela tem o caráter de atribuição de sentido a um texto que se manifesta na linguagem a partir de um processo de mediação com a Tradição, que é o espaço de atuação do jurista. A atividade interpretativa é sempre histórica, porque o texto somente é abordável a partir da historicidade do intérprete".

${ }^{88}$ A esse propósito, confira-se o escólio de STRECK, Lenio Luiz; ABBOUD, Georges. O que é isto: o precedente judicial e as súmulas vinculantes? 3. ed. Porto Alegre: Livraria do Advogado, 2015. p. 86: “(...) a integridade na aplicação do direito significa reconstrução histórica da cadeia de casos interpretados/julgados (doutrina e jurisprudência)".

${ }^{89}$ DWORKIN, Ronald. A justiça de toga. Tradução de Jefferson Luiz Camargo. São Paulo: Martins Fontes, 2016. p. 200. 
um direito (constitucional) consuetudinário com plena qualidade de norma. Além disso, mesmo no âmbito do direito vigente, a normatividade que se manifesta em decisões práticas não está orientada linguisticamente apenas pelo texto da norma jurídica concretizada. A decisão é elaborada com ajuda de ma-teriais legais, de manuais didáticos, de comentários e estudos monográficos, de precedentes e de material do Direito Comparado, quer dizer, com ajuda de numerosos textos que não são idênticos ao que transcendem o teor literal da norma ${ }^{90}$. (grifo nosso)

A norma, portanto, só é alcançada; produzida ao final. Antes, o que se tem é enunciado normativo ${ }^{91}$. E, no caso específico do Direito Eleitoral, a doutrina ainda está com a cabeça no modelo antigo. José Jairo Gomes assevera que são fontes desse microssistema apenas aquelas "normas jurídicas emanadas do Estado, em geral decorrentes de regular processo legislativo, constitucional ou infraconstitucional"92.

Por sua vez, Frederico Franco Alvim, com esteio no magistério de Miguel Reale, defende que "a despeito de sua magnitude, não se admite que a atividade judicante pretenda açambarcar o processo de gênese normativa" ${ }^{\prime 9}$.

Parece estar com razão Antônio Veloso Peleja Júnior que, ao tratar do "Direito Eleitoral e suas normas", enfatiza a influência das decisões da Corte Superior Eleitoral em relação às instâncias inferiores, as quais, segundo o autor, são ordinariamente seguidas de forma pacífica pelos juízes e Tri-

${ }^{90}$ MÜLLER, Friedrich. Métodos de trabalho do direito constitucional. Porto Alegre: Síntese, 1999. p. 54-5.

91 "Norma, dessa forma, seria a interpretação conferida a um texto (enunciado), parte de um texto ou combinação de um texto. Não existe norma antes da interpretação ou independentemente dela. Interpretar é produzir uma norma e ela é produto do intérprete". (ABBOUD, Georges. Processo constitucional brasileiro. São Paulo: Revista dos Tribunais, 2016. p. 65)

${ }^{92}$ GOMES, José Jairo. Direito Eleitoral. 13. ed. rev. e atual. São Paulo: Atlas, 2017. p. 31. É bem verdade que o autor, no rol estabelecido nas páginas 32 e 33, cita - após mencionar a Constituição, os Tratados Internacionais e as legislações domésticas - as consultas e as decisões da Justiça Eleitoral. Entretanto, quanto à consulta, assevera ser ato normativo em tese "sem efeitos concretos", isto é, sem "força executiva", ou seja, sem a nota da vinculação, própria dos precedentes. Quanto às decisões judiciais, diz carecerem estas de "nota de generalidade", ou seja, apregoa a eficácia meramente inter partes dos pronunciamentos da Corte de Vértice, ignorando o caráter transcendental dessas decisões.

${ }^{93}$ ALVIM, Frederico Franco. Curso de Direito Eleitoral. 2. ed. rev. e atual. Curitiba: Juruá, 2016. p. 41. O autor, todavia, reconhece, acertadamente, a resposta às consultas como "uma espécie de fonte formal de Direito Eleitoral". 
bunais Regionais Eleitorais. Essa realidade, sustenta, "tende a se acentuar em face da edição do novo CPC, que estimula a adoção dos precedentes"

Mas isso não significa, evidentemente, uma ampla e perigosa carta branca ao Poder Judiciário. Consoante advertência de Georges Abboud, "ao afirmar que o processo interpretativo é produtivo e não reprodutivo, não pode dar azo a interpretações fruto de uma compreensão equivocada do que se fala. $\mathrm{O}$ produtivo aqui mencionado não se refere a um ativismo judicial desmedido a partir do qual o próprio juiz criaria a lei para o caso" 95 .

Forte nessa preocupação tocante aos limites da interpretação judicial, Ana Paula de Barcellos, em reflexivo excerto, bem delimita o término da função do Legislativo e o papel posterior do Poder Judiciário na significação dos enunciados normativos:

(...) Por outro lado, no entanto, é certo que as atividades legislativa e jurisdicional não são fungíveis, e, embora possa haver áreas de aproximação importantes, existem igualmente distinções fundamentais que estruturam o próprio Estado democrático de direito. Continua a ser vedado ao juiz, em um Estado democrático de direito, inovar na ordem jurídica sem fundamento majoritário, sob pena de usurpar a competência própria dos demais poderes estatais. Entretanto, quais são essas distinções e, portanto, quais os limites da atividade jurisdicional, em face do princípio da legalidade? Qual o ponto de equilíbrio?

Os limites tradicionais que conduziam a atividade jurisdicional eram, e continuam a ser, os elementos semântico, histórico, sistemático e teleológico de intepretação. A decisão judicial deve se reportar a um texto normativo compreendido no sistema no qual se insere, tendo a Constituição em seu cimo hierárquico. Ainda que o texto não seja unívoco, não admitirá uma infinidade de interpretações, estabelecendo desde logo um campo máximo possível de sentidos ${ }^{96}$.

\footnotetext{
${ }^{94}$ PELEJA JÚNIOR, Antônio Veloso. Direito Eleitoral: aspectos processuais, ações e recursos. 5. ed. rev. e atual. Curitiba: Juruá, 2018. p.44.

${ }^{95}$ Ibidem, p. 80.

${ }^{96}$ BARCELLOS, Ana Paula de. op. cit., 662.
} 
Portanto, a função criadora da atividade interpretativa encontra limite na vinculação da decisão judicial ao sentido possível de um texto normativo e no sistema ${ }^{97}$ no qual está inserido. Tal premissa é inafastável ${ }^{98}$.

No fundo, a discussão remonta à preocupação a propósito da separação entre direito e política ${ }^{99}$ (como se fosse possível fazer uma cisão integral). É que a aplicação do direito contempla, dada a inevitável incompletude das leis gerais, a atividade supletiva do magistrado, o qual, como cidadão inserido dentro de uma dada ordem social, não pode ser tido por um ser totalmente neutro ${ }^{100}$.

\section{Nesse sentido, Dieter Grimm, ao tratar da tensão entre política e direito, ensina:}

Tal despolitização interna da aplicação do direito pressuporia que as normas jurídicas deliberadas pelo legislador pudessem determinar por completo a decisão de todos os fatos isolados, mas isso só seria o caso se na legislação estivessem previstos todos os casos possíveis de ocorrer e estes fossem regulamentados pela lei. Uma ordem jurídica que quisesse satisfazer essa condição deveria ser livre de lacunas e de

${ }^{97}$ MARINONI, Luiz Guilherme. A Ética dos Precedentes: justificativa do Novo CPC. 2. ed. rev. e atual. São Paulo: Revista dos Tribunais, 2016. p. 100: “(...) mais do que as partes envolvidas no litígio, toda a sociedade tem interesse em controlar o exercício do poder das Cortes Supremas. Mais claramente, têm concreto interesse todos àqueles que podem ser potencialmente atingidos pela solução instituída no precedente. Resulta disso é a técnica que abre oportunidade para a intervenção de amicus curiae no STF e no STJ".

${ }^{98}$ Por todos os críticos, ELY, John Hart. Democracia e desconfiança: uma teoria do controle judicial de constitucionalidade. São Paulo: Martins Fontes, 2016. p. 79: "Nossa sociedade não tomou a decisão constitucional de facultar o sufrágio universal para depois dar meia volta e sobrepor às decisões populares os valores dos juristas de primeiro escalão".

${ }^{99}$ GRIMM, Dieter. Constituição e política. Tradução: Geraldo de Carvalho. Belo Horizonte: Dey Rel, 2006. p. 14-5: "A separação entre direito e político no nível de aplicação do direito é uma separação institucional. Ela protege os órgãos da jurisdição em sua atividade aplicadora diante de qualquer influência por parte da política, particularmente por parte dos órgãos públicos decisórios e dos partidos políticos neles atuantes. 0 caminho unicamente legítimo do controle de conteúdo da jurisdição reside na promulgação das normas gerais que devem ser utilizadas pelos tribunais e das quais estes não podem se dispensar. Caso a aplicação das normas pelos tribunais conduza a resultados indesejados politicamente, estes podem ser corrigidos no futuro por uma reforma da norma, mas não por influência sobre processos correntes, ficando, assim, excluídas influências políticas externas sobre a aplicação do direito".

${ }^{100}$ GRIMM, Dieter. op. cit., p. 15: “(...) a separação entre direito e política no nível da aplicação do direito não significa que o procedimento da aplicação judicial do direito também seja internamente apolíitico, ou seja, não deixe espaço para nenhum tipo de decisões constitutivas ou não possa desenvolver nenhum efeito político que ultrapasse o efeito político das normas gerais". 
contradições, inequívoca na linguagem e independente de mudança social. Só essa listagem já basta para deixar claro que não se pode contar com uma ordem jurídica assim. As normas gerais somente são capazes de determinar mais ou menos a solução de casos individuais. A dimensão da determinação depende de vários fatores, em especial da densidade da regulamentação, da idade das normas jurídicas e da dinâmica do objeto de regulamentação. Mas não há nenhuma norma jurídica, cuja aplicação não suscite, algum dia, dúvidas que precisem ser esclarecidas pelo juiz por intermédio de concretização e interpretação. Para tanto, são inevitáveis influências da pré-compreensão, da origem e socialização, das preferências políticas e ideológicas dos juízes ${ }^{101}$.

Mas isso não implica autonomia absoluta. O exercício da jurisdição é um ato racional e não arbitrário. Por mais que os magistrados possuam preferências políticas e ideológicas, suas decisões são pautadas, em última instância, pelos precedentes.

Não é por outra razão que Hermes Zaneti Jr. defende o uso de precedentes como "uma garantia de fechamento e não de abertura dos poderes discricionários do juiz"102.

Daí também a importância do conceito de justiça formal entabulado por Neil MacCormick. O autor parte do pressuposto de que há uma dupla coerção incidente sobre o juiz, uma voltada para o passado e outra para o futuro ${ }^{103}$.

Tais coerções impedem arbítrios e legitimam o sistema de precedentes, como bem se pode compreender do seguinte excerto de sua obra:

O tribunal que hoje decide um caso específico entre indivíduos deveria levar em conta seu dever, pelo menos seu dever inicial, de decidir o caso em termos compatíveis com decisões anteriores sobre as mesmas questões ou questões semelhantes. No mínimo, a justiça

${ }^{101}$ Ibidem, p. 15.

102 ZANETI JR., Hermes. O valor vinculante dos precedentes: Teoria dos Precedentes Normativos Formalmente Vinculantes. 2. ed. rev. e atual. Salvador: Juspodivm, 2016. p. 20. ${ }^{103}$ MacCORMICK, Neil. op. cit., p. 95: "Por banal que seja o fato de que as exigências da justiça formal estabelecem no mínimo uma razão presumivel para a observância de precedentes, não é menos verdadeiro, embora seja observado com menor frequência, que essas exigências impõem sobre a decisão de disputas levadas a juízo, coerções tanto voltadas para o futuro como para o passado". 
formal exige que, exceto por fortes razões, ele não decida o caso atual de uma forma diferente da adotada em suas decisões anteriores em casos semelhantes. Ao decidir esse caso, o tribunal não terá então o dever - de igual importância - de levar em conta o precedente que estará estabelecendo para casos ainda por surgir? O dever que tenho de tratar casos semelhantes de modo semelhante implica que devo decidir o caso de hoje com fundamentos que eu esteja disposto a adotar para a decisão de casos semelhantes no futuro, exatamente tanto quanto implica que hoje eu deva levar em consideração minhas decisões anteriores em casos semelhantes no passado. As duas implicações são implicações de adesão ao princípio da justiça formal; e quem quer que concorde quanto ao dever dos juízes de acatar o princípio da justiça formal está comprometido com essas duas implicações ${ }^{104}$.

O sistema de precedentes ${ }^{105}$ - no qual o Brasil acaba inserido, em especial pelo Novo Código de Processo Civil, como será mais bem detalhado em linhas futuras - depende de uma rigorosa deontologia ${ }^{106}$ profissional dos juízes. Há de se ter compromisso intransigente com essa postura contemplativa da cadeia de precedentes.

De todo modo, a referida preocupação não é em vão, pelo contrário. O que se observou, pelo menos no contexto brasileiro pré-NCPC, é que a doutrina não vinha cumprindo seu papel ${ }^{107}$. E os Tribunais, num

${ }^{104}$ MacCORMICK, Neil. op. cit., p. 96.

105 "Diferentemente do civil law, no qual duas rupturas históricas são características indispensáveis para sua compreensão, a tradição de common law é caracterizada por sua continuidade: é uma evolução histórica marcada por um elevado grau de constância". (MACÊDO, Lucas Buril de. Precedentes judiciais e o direito processual civil. op. cit., p. 45).

${ }^{106}$ Esse modus procedendo é assim registrado por MacCormick [op. cit., p. 98]: “(...) ou nossa sociedade é organizada de acordo com esse valor da racionalidade ou não, e não consigo contemplar sem repugnância a incerteza e a insegurança de uma sociedade gerida arbitrariamente, na qual decisões de todas as espécies são tomadas de acordo com a veneta ou o capricho de alguém naquele momento, sem referência a processos decisórios passados ou futuros".

${ }^{107}$ Lucas Buril de Macêdo [op. cit., p. 56-7] chama a atenção para o papel destacadamente secundário da doutrina no sistema common law, do qual o Brasil vem se aproximando com o stare decisis à brasileira (sistema de precedentes obrigatórios). Conforme narra o autor, "os jovens que quisessem se fazer juristas iam morar nos Inns of Courts e aprender como se faz direito com aqueles que o praticam: os baristers e os juízes". E prossegue: "O lugar adequado, na Inglaterra, para aprender o direito é no tribunal. Somente no século XIX é que a formação universitária passou a ganhar importância na Inglaterra, e só atualmente a maioria das pessoas buscam um diploma em direito para 
campo livre em decorrência da eloquente aquiescência ou condescendência dos doutrinadores (estes, no mais das vezes, caudatários; meros reprodutores das decisões judiciais), vinham instituindo uma jurisprudência lotérica ${ }^{108}$, descompromissada com o sistema jurídico como um todo.

Por todos os críticos desse estado de coisas, é forçoso registrar a crítica do professor Adriano Soares da Costa:

Em um universo de conceitos jurídicos vazios, em que a doutrina se despede de fazer o seu mister, fica a jurisprudência livre para usar os conceitos normativos de qualquer modo, como se fossem destituídos de conteúdo. Com isso, até mesmo a inelegibilidade deixa de ser sanção para ser um "sabe-se-lá-o-quê". É ainda onde mais nitidamente se percebe o terrível vazio normativo decorrente do vazio teórico: os institutos jurídicos passam a ser usados de qualquer modo e jeito para atender a quaisquer fins e bandeiras. Há apenas, como consectário disso, a irracionalidade jurídica, o decisionismo voluntarista e uma crise de segurança jurídica ${ }^{109}$.

Ingeborg Maus, analisando o contexto específico do Tribunal Constitucional alemão, salienta o risco de os tribunais praticarem uma espécie de teologia jurídica ${ }^{110}$. Criticando o Tribunal alemão, a autora denuncia

exercerem as profissões jurídicas. A formação dos juristas do common law é marcadamente prática e não teórica, no que se distingue da que se dá nos países de civil law, marcados pela formação escolástica das universidades". Esse registro é importante para se avaliar o futuro da doutrina jurídica nesse novo sistema de precedentes defendido por Luiz Guilherme Marinoni e Daniel Mitidiero, dentre outros.

${ }^{108}$ A expressão é de Lênio Streck em: STRECK, Lenio Luiz; ABBOUD, Georges. O queé isto: o precedente judicial e as súmulas vinculantes? 3. ed. Porto Alegre: Livraria do Advogado, 2015. p. 19.

${ }^{109}$ SOARES DA COSTA, Adriano. Instituições de Direito Eleitoral: Teoria da Inelegibilidade: Direito Processual Eleitoral. 9. ed., Belo Horizonte: Fórum, 2013. p. 15.

${ }^{110}$ MAUS, Ingeborg. Judiciário como superego da sociedade: o papel da atividade jurisprudencial na "sociedade órfã". Revista Novos Estudos CEBRAP, São Paulo, n. 58, p. 183-202, nov. 2000. p. 192: "A apropriação da persecução de interesses sociais, de processos de formação da vontade política e dos discursos morais por parte da mais alta corte é alcançada mediante uma profunda transformação do conceito de Constituição: esta deixa de ser compreendida - tal qual nos tempos da fundamentação racional-jusnaturalista da democracia - como documento da institucionalização de garantias fundamentais das esferas de liberdade nos processos políticos e sociais, tornando-se um texto fundamental a partir do qual, a exemplo da Bíblia e do Corão, os sábios deduziriam diretamente todos os valores e comportamentos corretos. O TFC, em muitos de seus votos de maioria, pratica uma "teologia constitucional". 
também o que chama de autorreferencialismo das $\operatorname{Cortes}^{111}$, quando os julgadores passam a desconsiderar o direito e se preocupam, exclusivamente, com a sua própria história jurisprudencial ${ }^{112}$.

De se ver, portanto, e a doutrina assim denuncia, que é preciso impor limites à atividade interpretativa, de modo a se evitar posturas voluntaristas e a figura do criacionismo judicial, a comprometer o próprio sistema de separação dos poderes ${ }^{113}$.

Feita a necessária advertência, cumpre concluir salientando que não é o escopo do presente trabalho analisar os métodos de interpretação/ aplicação do direito, mas apenas o de reconhecer a constatação amplamente aceita, até por seus críticos - por todos, Ingeborg Maus -, de que "as leis são reconhecidas indiferenciadamente como meras previsões e premissas da atividade decisória judicial"114.

${ }^{111}$ Oportuno destacar o famoso voto do Ministro Humberto Gomes de Barros em julgado no Superior Tribunal de Justiça (AgReg em ERESP n 279.889-AL): "Não me importa o que pensam os doutrinadores. Enquanto for ministro do Superior Tribunal de Justiça, assumo a autoridade da minha jurisdição. O pensamento daqueles que não são ministros deste Tribunal importa como orientação. A eles, porém, não me submeto. Interessa conhecer a doutrina de Barbosa Moreira ou Athos Carneiro. Decido, porém, conforme minha consciência. Precisamos estabelecer nossa autonomia intelectual, para que este Tribunal seja respeitado. É preciso consolidar o entendimento de que os Srs. ministros Francisco Peça- nha Martins e Humberto Gomes de Barros decidem assim, porque pensam assim. E o STJ decide assim, porque a maioria de seus integrantes pensa como esses ministros. Esse é o pensamento do Superior Tribunal de Justiça e a doutrina que se amolde a ele. É fundamental expressarmos o que somos. Ninguém nos dá lições. Não somos aprendizes de ninguém. Quando viemos para este Tribunal, corajosamente assumimos a declaração de que temos notável saber jurídico - uma imposição da Constituição Federal. Pode não ser ver- dade. Em relação a mim, certamente, não é, mas, para efeitos constitucionais, minha investidura obriga-mea pensar que assim seja".

${ }^{112}$ MAUS, Ingeborg. op. cit., p. 192: "Por conta de seus métodos específicos de interpretação constitu- cional, atua o TFC menos como 'Guardião da Constituição' do que como garantidor da própria história jurisprudencial, à qual se refere legitimidade de modo autorreferencial. Tal história fornece-lhe fundamentações que não necessitam mais ser justificadas, sendo somente descritas retrospectivamente dentro de cada sistema de referências".

${ }^{113}$ Ibidem. p. 187: "Quando a Justiça ascende ela própria à condição de mais alta instância moral da sociedade, passa a escapar de qualquer mecanismo de controle social - controle ao qual normalmente se deve subordinar toda instituição do Estado em uma forma de organização política democrática. No domínio de uma Justiça que contrapõe um direito 'superior', dotado de atributos morais, ao simples direito dos outros poderes do Estado e da sociedade, é notória a regressão a valores pré-democráticos de parâmetros de integração social".

${ }^{114}$ Op. cit., p. 193. 
À guisa de conclusão: o direito atualmente também deve ser compreendido como a interpretação conferida às leis do Parlamento pelos Tribunais por meio de decisões fundamentadas e atualmente acessíveis ${ }^{115}$ aos cidadãos, e sobretudo à comunidade jurídica, pelos novos meios de comunicação que permitem o conhecimento em tempo instantâneo de todos os julgamentos do Poder Judiciário ${ }^{116}$. Assim, não há mais espaço para planejamento jurídico sem o domínio dos precedentes ${ }^{117}$, os quais passaram a ter força cogente em conjunto com o acervo legislativo pátrio.

\section{Considerações finais}

A teor do que exposto, é possível concluir que não há mais espaço para uma teoria da decisão judicial que ignora o papel dos precedentes enquanto fontes do direito ${ }^{118}$.

$\mathrm{O}$ ordenamento jurídico não se limita ${ }^{119}$, portanto, às normas emanadas pelos órgãos legal e constitucionalmente competentes para produzir

${ }^{115}$ MACÊDO, Lucas Buril de. op. cit., p. 292-3: "Só é possível a construção de um sistema de precedentes obrigatórios a partir de instrumentos eficazes de publicidade das decisões. A cognoscibilidade do Direito é requisito essencial do princípio da segurança jurídica e para a concretização do ideal do Estado de Direito, sendo indispensável que seja possível aos cidadãos conhecer os textos de onde serão coligidas normas jurídicas. A partir do momento em que se tem a decisão judicial como fonte do direito, é indispensável inseri-la neste contexto: do ato judicial será extraída uma norma jurídica que terá aplicação a todos os jurisdicionados, sendo direito fundamental destes, portanto, tomar conhecimento apropriadamente do Direito que rege suas ações".

${ }^{116}$ MACÊDO, Lucas Buril de. op. cit., p. 295: “(...) o sistema pátrio de publicação permite que o jurisdicionado tenha acesso a todo o conteúdo da decisão, muitas vezes disponibilizando até mesmo o vídeo ou áudio da sessão de julgamento, fornecendo a íntegra dos votos de todos os juízes, inclusive a dos votos dissidentes. Essa prática permite um conhecimento aprofundado das razões da decisão, facilitando a reconstrução da ratio decidendi e também torna possivel antever a possibilidade de superação (overruling) do precedente".

${ }^{117}$ MITIDIERO, Daniel. Cortes Superiores e Cortes Supremas: do controle à interpretação, da jurisprudência ao precedente. 3. ed. São Paulo: Revista dos Tribunais, 2017. p. 35: “(...) é tarefa do precedente reduzir o âmbito de equivocidade inerente ao Direito, viabilizando a sua maior cognoscibilidade".

118 "O Novo Código de Processo Civil promoveu um grande avanço no reconhecimento do papel das decisões judiciais como fonte do direito e instituiu um sistema de precedentes vinculantes com amplitude e alcance inéditos para o país". (MELLO, Patrícia Perrone Campos; BARROSO, Luís Roberto. Trabalhando com uma nova lógica: a ascensão dos precedentes no direito brasileiro. Revista da AGU. Brasília, DF, v. 15, n. 3, p. 9-52, jul./set. 2016. p. 45).

119 "All Laws, written, or unwritten, have need of Interpretation" (HOBBES, Thomas. Leviathan, or the matter, forme, \& power of a common-wealth ecclesiastical and civil. London: 
leis e atos normativos, haja vista que o próprio Legislador, no curso corrente da história, relegou maior espaço à atuação do Judiciário, ao trabalhar, na própria confecção legislativa, cada vez mais com os conceitos jurídicos indeterminados, as cláusulas gerais e os princípios - como é o caso da Lei da Ficha-Limpa, por exemplo, na seara eleitoral.

Por outro lado, é cada vez mais destacado o papel do contexto fático no momento da decisão judicial, com apelo às peculiaridades que circundam cada litígio judicializado, o que acaba por minar a ideia de completude da norma em abstrato, própria do positivismo-legalista, ampliando as atribuições e atividades cognitivas dos magistrados, os quais passam a contribuir para o desenvolvimento do Direito posto, completando-o nos espaços próprios de cada dispositivo legal, de acordo com os valores e a principiologia inerente ao respectivo microssistema ${ }^{120-121}$.

Cabe aqui, por todos, a definição de François Ost em sua teoria lúdica do direito:

Antes de ser regla e institución, el Derecho es logos, discurso, significado en suspenso. Se articula "entre" las cosas: entre la regla (que no es nunca enteramente normativa) y el hecho (que no es nunca enteramente fáctico), entre el orden y el desorden, entre la letra y el espíritu, entre la fuerza y la justicia. Dialéctico, es el uno "por" el otro; paradójico, es el uno y otro ${ }^{122}$.

Andrew Croke, 1651. p. 143 apud ZANETI JR., Hermes. O valor vinculante dos precedentes: Teoria dos Precedentes Normativos Formalmente Vinculante. 2. ed. rev. e atual. Salvador: Juspodivm, 2016. p. 66.)

${ }^{120}$ ALVIM, Teresa Arruda; DANTAS, Bruno. Recurso Especial, Recurso Extraordinário e a nova função dos Tribunais Superiores. 5. ed. rev. e atual. São Paulo: Revista dos Tribunais, 2018. p. 47-53 (capítulo 2, subitem 2.1.: "a evolução da sociedade e o sistema jurídico").

${ }^{121}$ Especificamente quanto ao microssistema eleitoral, José Jairo Gomes adverte: "Para que um setor do universo jurídico seja inserido na categoria de microssistema, deve possuir princípios e diretrizes próprios, ordenados em atenção ao objeto regulado, que the assegurem a coerência interna de seus elementos e, com isso, identidade própria. Ademais, pressupõe a existência de práticas sociais específicas, às quais correspondam um universo discursivo e textual determinado a amparar as relações jurídicas ocorrentes. $O$ Direito Eleitoral atende a tais requisitos. Nele se encontra encerrada toda a matéria ligada ao exercício de direitos políticos e organização das eleições. Enfeixa princípios, normas e regras atinentes a vários ramos do Direito, como constitucional, administrativo, penal, processual penal, processual civil". (GOMES, José Jairo. Direito Eleitoral. 13. ed. São Paulo: Atlas, 2017. p. 29)

${ }^{122}$ OST, François. Júpiter, Hércules, Hermes: tres modelos de juez. Revista sobre enseñanza del Derecho, Buenos Aires, n. 8, p. 101-130, 2007. p. 122. 
Adotadas todas essas premissas, há uma clara percepção de que a segurança jurídica, assim entendida sob o viés da previsibilidade, não se contenta mais com o mero conhecimento da legislação positivada, pois muito do próprio sentido desta é revelado pelo Judiciário, em especial pelas Cortes Supremas, a evidenciar que os precedentes eleitorais, no contexto do desenho institucional da Justiça Eleitoral, são fontes primárias do Direito Eleitoral.

\section{Referências}

ABBOUD, Georges. Processo constitucional brasileiro. São Paulo: Revista dos Tribunais, 2016.

ADOMEIT, Klaus. Juristische Methode. In: GÖRLITZ, Axel (ed.). Handlexikon zur Rechtswissenschaft. München: Ehrenwirth, 1972. p. 217-220 apud MAUS, Ingeborg. Judiciário como superego da sociedade: o papel da atividade jurisprudencial na "sociedade órfã". Revista Novos Estudos CEBRAP, São Paulo, n. 58, p. 183-202, nov. 2000.

ALVIM, Frederico Franco. Curso de Direito Eleitoral. 2. ed. rev. e atual. Curitiba: Juruá, 2016.

ALVIM, Teresa Arruda; DANTAS, Bruno. Recurso Especial, Recurso Extraordinário e a nova função dos Tribunais Superiores. 5. ed. rev. e atual. São Paulo: Revista dos Tribunais, 2018.

ÁVILA, Humberto. Teoria dos princípios: da definição à aplicação dos princípios jurídicos. 12. ed. São Paulo: Malheiros Editores, 2011.

CANOTILHO, José Joaquim Gomes. Direito Constitucional e Teoria da Constituição. 7. ed. Coimbra: Almedina, 2003.

CARDOZO, Benjamin N. A natureza do processo judicial. Tradução de Silvana Vieira. São Paulo: Martins Fontes, 2004.

CATTONI DE OLIVEIRA, Marcelo Andrade. Direito Processual Constitucional. Belo Horizonte: Mandamentos, 2001.

DUARTE, Michelle Pimentel. Processo judicial eleitoral: jurisdição e fundamentos para uma Teoria Geral do Processo Judicial Eleitoral. Curitiba: Juruá, 2016.

DWORKIN, Ronald. A justiça de toga. Tradução de Jefferson Luiz Camargo. São Paulo: Martins Fontes, 2016. 
ELY, John Hart. Democracia e desconfiança: uma teoria do controle judicial de constitucionalidade. São Paulo: Martins Fontes, 2016.

FERRAZ JÚNIOR, Tércio Sampaio. O direito, entre o futuro e o passado. São Paulo: Noeses, 2014.

GADAMER, Hans-Georg. Verdade e método: traços fundamentais de uma hermenêutica filosófica. 2. ed. Rio de Janeiro: Vozes, 2004.

GOMES, José Jairo. Direito Eleitoral. 13. ed. São Paulo: Atlas, 2017.

GRIMM, Dieter. Constituição e política. Tradução: Geraldo de Carvalho. Belo Horizonte: Dey Rel, 2006.

HART, Herbert Lionel Adolphus. The Concept of Law. Oxford: Oxford University Press, 1994.

HOBBES, Thomas. Leviathan, or the matter, forme, \& power of a common-wealth ecclesiastical and civil. London: Andrew Croke, 1651.

KELSEN, Hans. Teoria Pura do Direito. Tradução: João Baptista Machado. 6. ed. São Paulo: Martins Fontes, 2003.

LAMEGO, José. Hermenêutica e jurisprudência: análise de uma recepção. Lisboa: Fragmentos, 1990.

LARENZ, Karl. Metodologia da ciência do direito. Tradução de José Lamego. 3. ed. Lisboa: Fundação Calouste Gulbenkian, 1997.

MacCORMICK, Neil. Argumentação jurídica e Teoria do Direito. Tradução de Waldéa Barcellos. 2. ed. São Paulo: Martins Fontes, 2009.

MACÊDO, Lucas Buril de. Precedentes judiciais e o direito processual civil. Salvador: Juspodivm, 2015.

MAIA FILHO, Napoleão Nunes. Princípios jurídicos e garantismo judicial: atitude antipositivista e jurisdição includente. Fortaleza: Imprece, 2016.

MARINONI, Luiz Guilherme. A Ética dos Precedentes: justificativa do Novo CPC. 2. ed. rev. e atual. São Paulo: Revista dos Tribunais, 2016.

. O precedente na dimensão da segurança jurídica. In: MARINONI, Luiz Guilherme (coord.). A força dos precedentes: estudos dos cursos de Mestrado e Doutorado em Direito Processual Civil da UFPR. Salvador: Juspodivm, 2010.

MAUS, Ingeborg. Judiciário como superego da sociedade: o papel da atividade jurisprudencial na "sociedade órfã". Revista Novos Estudos CEBRAP, São Paulo, n. 58, p. 183-202, nov. 2000. 
MELLO, Patrícia Perrone Campos; BARROSO, Luís Roberto. Trabalhando com uma nova lógica: a ascensão dos precedentes no direito brasileiro.

Revista da AGU. Brasília, DF, v. 15, n. 3, p. 9-52, jul./set. 2016.

MITIDIERO, Daniel. Cortes Superiores e Cortes Supremas: do controleà interpretação, da jurisprudência ao precedente. 3. ed. São Paulo: Revista dosTribunais, 2017.

MÜLLER, Friedrich. Métodos de trabalho do direito constitucional. Porto Alegre: Síntese, 1999.

NEVES, Antonio Castanheira. Metodologia jurídica: problemas fundamen- tais. Coimbra: Coimbra Editora, 1993.

PELEJA JÚNIOR, Antônio Veloso. Direito Eleitoral: aspectos processuais, ações e recursos. 5. ed. rev. e atual. Curitiba: Juruá, 2018.

OST, François. Júpiter, Hércules, Hermes: tres modelos de juez. Revistasobre enseñanza del Derecho, Buenos Aires, n. 8, p. 101-130, 2007.

SCHAUER, Frederick. Thinking like a lawyer: a new introduction to legalreasoning. Cambridge: Harvard University Press, 2012.

SOARES DA COSTA, Adriano. Instituições de Direito Eleitoral: Teo- ria da Inelegibilidade: Direito Processual Eleitoral. 9. ed. Belo Horizonte: Fórum, 2013.

STRECK, Lenio Luiz. O que é isto: decido conforme minha consciência? 2.ed. Porto Alegre: Livraria do Advogado, 2010.

; ABBOUD, Georges. $\mathbf{O}$ que é isto: o precedente judicial e as súmu-las vinculantes? 3. ed. Porto Alegre: Livraria do Advogado, 2015.

Precedentes judiciais e hermenêutica: o sentido da vinculação no CPC/2015. Salvador: Juspodivm, 2018.

ZANETI JR., Hermes. O valor vinculante dos precedentes: Teoria dos Precedentes Normativos Formalmente Vinculantes. 2. ed. rev. e atual. Salva-dor: Juspodivm, 2016.

Rodrigo Cyrineu - Advogado e Procurador-Geral da Câmara Municipal de Cuiabá. Mes- tre em Direito Constitucional pelo Instituto Brasiliense de Direito Público (IDP). Especia- lista em Direito Administrativo, Direito Constitucional e Direito Eleitoral pela Fundação Escola Superior do Ministério Público de Mato Grosso. Membro-fundador da ABRADEP (Academia Brasileira de Direito Eleitoral e Político). 